\title{
Effectiveness of Spinal Endoscopic Adhesiolysis in Post Lumbar Surgery Syndrome: A Systematic Review
}

Salim M. Hayek, MD, PhD', Standiford Helm, MD², Ramsin M. Benyamin, MD³, Vijay Singh, MD', David A. Bryce, MD ${ }^{5}$, and Howard S. Smith, MD

From: ${ }^{1}$ University Hospitals and Outcomes Research Consortium, Cleveland, $\mathrm{OH} ;{ }^{2}$ Pacific Coast Pain Management Center, Laguna Hills, CA; ${ }^{3}$ Millennium Pain Center, Bloomington, IL; ${ }^{4}$ Pain Diagnostics Associates, Niagara, Wl; ${ }^{5}$ Advanced

Pain Management, Middleton, Wl; and, ${ }^{6}$ Albany Medical College Albany, NY

Dr. Hayek is Chief of the Division of Pain Medicine, Department of Anesthesiology, University Hospitals of Cleveland, Cleveland, $\mathrm{OH}$; and a member of the Outcomes Research Consortium, Cleveland, OH. Dr. Helm is Medical Director, Pacific Coast Pain

Management Center, Laguna Hills, CA. Dr. Benyamin is Medical Director, Millennium Pain Center, Bloomington, $\mathrm{IL}$, and Clinical Assistant Professor of Surgery, College of Medicine, University of Illinois, UrbanaChampaign, IL. Dr. Singh is Medical Director of Pain Diagnostics Associates, Niagara, WI. Dr. Bryce is with Advanced Pain Management, Middleton, WI. Dr. Smith is Associate

Professor and Academic Director of Pain Management for Albany Medical College Department of Anesthesiology, Albany, NY.

Address correspondence: Salim M. Hayek, MD, PhD Division of Pain Medicine University Hospitals 11100 Euclid Ave Cleveland, $\mathrm{OH} 44106$ Email: salim.hayek@UHhospitals.

Disclaimer: There was no external funding in the preparation of this manuscript.

Manuscript received: 02/18/2009 Accepted for publication: 03/10/2009

Free full manuscript: www.painphysicianjournal.com
Background: Post lumbar surgery syndrome with persistent chronic low back and lower extremity pain is common in the United States. Epidural fibrosis may account for as much as $20 \%$ to $36 \%$ of all cases of failed back surgery syndrome (FBSS). Percutaneous adhesiolysis with a catheter or direct visualization of the spinal canal and the contents with an endoscope are techniques employed in resistant cases when patients fail to respond to conservative modalities of treatment, including fluoroscopically directed epidural injections. Some patients failing to respond to percutaneous adhesiolysis are candidates for spinal endoscopic adhesiolysis. However, literature evaluating the effectiveness of spinal endoscopic adhesiolysis is sparse and discussions continue about its effectiveness, utility, and complications.

Study Design: A systematic review of the available literature.

Objective: To evaluate the effectiveness and safety of spinal endoscopic adhesiolysis in the management of chronic low back and lower extremity pain in post surgical patients with chronic recalcitrant pain, non-responsive to conservative modalities of management and fluoroscopically directed epidural injections.

Methods: A search of relevant resources (PubMed, EMBASE, and the Cochrane database) was accomplished and the resulting publications were examined based on the inclusion/exclusion criteria set forth. Randomized controlled trials and observational studies were included in the search. Two reviewers assessed the studies' methodologies and outcomes. Randomized clinical trials were assessed and scored based on the criteria established by the Cochrane methodological assessment criteria of randomized clinical trials and the observational studies were assessed and scored based on the Agency for Healthcare Research and Quality (AHRQ) criteria.

Clinical relevance was evaluated utilizing Cochrane review criteria.

Analysis was conducted using 5 levels of evidence, ranging from Level I to III, with 3 subcategories in Level II.

Outcome Measures: The primary outcome measure was pain relief ( $\geq 50 \%)$ in follow-up for at least 6 months. Pain relief for longer than 6 months was considered long-term and 6 months or less was considered short-term. The secondary outcome measures were functional and psychological status, return to work, patient satisfaction, and opioid intake.

Results: Of the 13 studies considered for inclusion, one randomized trial and 5 observational studies met inclusion criteria for evidence synthesis based on the inclusion criteria and methodologic quality scores of 50 or more.

The indicated level of evidence for endoscopic adhesiolysis is Level II-1 or II-2 evidence for shortand long-term relief based on the U.S. Preventive Services Task Force (USPSTF) criteria.

Limitations: There was a paucity of literature for randomized trials.

Conclusion: Spinal endoscopic adhesiolysis may be used as an effective treatment modality for chronic refractory low back pain and radiculopathy that is related to epidural adhesions.

Key words: Chronic low back pain, lower extremity pain, lumbar post surgery syndrome, failed back surgery syndrome, percutaneous adhesiolysis, endoscopic adhesiolysis, epidural adhesions, epidural fibrosis

Pain Physician 2009; 12:419-435 
ailed back surgery syndrome (FBSS), representing a cluster of symptoms following spine surgery, is also described as post lumbar laminectomy syndrome or post surgery syndrome (15). Persistent, chronic, disabling pain which is nonresponsive to various modalities of conservative and interventional treatments following lumbar spine surgery is common (1-11). Due to an exponential increase in surgical interventions, it appears that the cost of persistent pain following lumbar spine surgery also continues to increase (12-22). In addition, the literature continues to demonstrate an increase in prevalences and care seeking for spinal pain $(23,24)$.

Animal models of post lumbar laminectomy syndrome demonstrate paraspinal muscle spasms, tail contractures, pain behaviors, tactile allodynia, epidural and perineural scarring, and nerve root adherence to the underlying disc and pedicle (25-30). Various causes of post surgery syndrome or FBSS include epidural fibrosis, acquired stenosis, internal disc disruption, recurrent disc herniation, facet joint pain, sacroiliac joint pain, arachnoiditis, segmental instability, and others (1-8,17,3137). Epidural fibrosis may account for as much as $20 \%$ to $36 \%$ of all cases of FBSS $(6,7,31,33-37)$. Further, a final common pathway resulting in peripheral and central facilitation potentiated by inflammatory and nerve injury mechanisms has been described (25-30). A correlation between peridural scarring and radicular pain $(6,38-40)$ and poor clinical outcomes (41) have been reported. However, others (42-44) have questioned the role of epidural fibrosis as a causative factor.

While the mechanism of FBSS pain could involve a long list of pathologies, it is accepted that epidural adhesions that develop following surgical manipulation of the space or small hematomas may be an important etiologic factor $(6,7,33,34,45,46)$. Epidural fibrosis could trigger nociceptive activity as it compresses the nerve roots (47). Further, epidural fibrosis restricts the movement of nerves through the nerve sleeves and decreases the flexibility of the nerve roots by tethering them (47).

Epidural procedures for managing chronic low back are one of the most commonly performed interventions in the United States (48-60). However, only a moderate proportion of these patients show improvement in pain and functional level with interventional pain management procedures, including epidural injections and adhesiolysis (1,61-70).

Imaging techniques such as computed tomography $(C T)$ and magnetic resonance imaging (MRI) are not specific and cannot identify epidural fibrosis. Direct visualization of the pathologic changes inside the spinal canal may be necessary to confirm the diagnosis and additionally can be used as a therapeutic tool in dissecting fibrotic tissue and injecting medications. Indeed, instrumentation with epidural endoscopes in patients with chronic back pain has been used for mechanical adhesiolysis (breaking up adhesions by pulling and dissecting), sheer volume adhesiolysis (injecting a relatively large volume of saline), and target-directed delivery of steroids close to the affected nerve root(s).

Spinal endoscopic adhesiolysis has emerged during the 1990s after years of advances in instrumentation. Imaging tools and fiberoptic technology made possible the development of small flexible endoscopes with high image resolution. The historical perspective of spinal endoscopy is well described by Manchikanti et al (36). Current U.S. Food and Drug Administration (FDA) approved indications for the use of spinal endoscopy are as follows: documentation of pathological features, documentation of decompression of structures, direct nerve inspection, inspection of internal fixation, and delivery of therapeutic agents.

Spinal endoscopic adhesiolysis offers potential advantages in the management of chronic refractory low back and leg pain, including direct visualization of spinal structures allowing specific adhesiolysis and targeted deposition of medications. Nonetheless, effective application of this technology warrants evaluation of clinical trials to determine its efficacy in the context of specific clinical conditions and analysis of risks associated with the procedure.

This systematic review is undertaken to evaluate the effectiveness of spinal endoscopic adhesiolysis in treating low back and/or radicular pain in patients with failed low back surgery syndrome.

\section{Methods}

\section{Search Strategy}

Bibliographic resources such as PubMed, CINAHL, EMBASE, Cochrane Database of Systematic Reviews, and Cochrane Controlled Trials Register were used to search for English language studies published from 1966 until December 2008. Keywords used to search were spinal adhesions, adhesiolysis, epidural adhesiolysis, epiduroscopy, lumbar post surgery syndrome, lumbar post-laminectomy syndrome, and failed back surgery syndrome. 


\section{Study Selection}

Search results from all databases were combined and duplicates were removed. Reference lists from retrieved articles were also reviewed for additional relevant studies that were not identified in our search. All articles were triaged for inclusion by the first author for suitability prior to review.

Inclusion criteria included all studies evaluating the role of spinal endoscopy as a therapeutic tool for adhesiolysis in managing chronic low back pain with or without lower extremity pain secondary to post lumbar surgery syndrome. All the patients should have tried and failed conservative management, including fluoroscopically directed epidural injections.

Exclusion criteria included non-clinical studies, expert opinions, reports without appropriate diagnosis, non-systematic reviews, book chapters, and case reports.

\section{Outcome Measurements}

Significant pain relief ( $\geq 50 \%$ ) of short-term ( $\leq 6$ months) and long-term (> 6 months) was the primary outcome measure. Secondary outcomes included functional or psychological improvement, improvement in work status, and complications.

\section{Methodological Quality Assessment}

The methodologic quality of each individual article used in this analysis was assessed by the Agency for Healthcare Research and Quality (AHRQ) criteria for assessment of observational studies (71) and modified Cochrane review criteria with weighted scores (72) for randomized trials and with consensus-based weighted scoring developed by the guidelines committee of the American Society of Interventional Pain Physicians (ASIPP). These criteria have been revised and also have been utilized in other publications $(68,73-83)$. A standardized form was used to extract the relevant data on the methods used, participants, interventions, outcome measures used and timing of outcome measurement, reported side effects, and the main results. Studies could earn points for each criterion met with a maximum score of 100 points. The authors independently scored each article using the method described. Only studies scoring 50 or above were used in the analysis. Any discrepancies or conflicts were arbitrated by a third reviewer to either reach a consensus agreement or break a tie. If there was a conflict of interest with the reviewed manuscripts with authorship or any other type of conflict, the involved authors did not review the manuscripts for quality assessment or evidence synthesis.

Observational studies were only included in the evidence synthesis if there were less than 4 randomized trials meeting the inclusion criteria.

\section{Clinical Relevance}

Clinical relevance of the included studies was evaluated according to 5 questions recommended by the Cochrane Back Review Group $(60,84)$. Each question was scored positive (+) if the clinical relevance item was met, negative (-) if the item was not met, and unclear (?) if data were not available to answer the question.

In the recent Cochrane review of "Injection Therapy for Subacute and Chronic Low Back Pain" (60) the authors considered a $20 \%$ improvement in pain scores (85) and a $10 \%$ improvement in functioning outcomes (86) to be clinically important. This study utilized stricter criteria than general systematic reviews and previous systematic reviews. Any relief of 6 months or less was considered as short-term, whereas Cochrane reviews (60) and others have considered 6 weeks as short-term and longer than 6 weeks as long-term. We also utilized very strict methodologic quality assessment criteria (60) to minimize inclusion, thus this systematic review is expected to provide robust results because of the stricter criteria. Further, in contrast to many other systematic reviews, in this systematic review, observational studies with scores of 50 or more on a scale of $0-100$ based on AHRQ criteria were included. This improves the generalizability of the systematic review as well as the intervention (87-91).

\section{Qualitative Analysis of Evidence}

A qualitative analysis was conducted using 5 levels of evidence for effectiveness of spinal endoscopic adhesiolysis as illustrated in Table 1. The levels of evidence range from Level I to Level III, with Level II having 3 subcategories (92).

\section{Recommendations}

Qualitative recommendations relative to the quality of evidence for each outcome was judged based on criteria established by Guyatt et al (93) as shown in Table 2.

\section{Outcomes of the Studies}

A study was judged to be positive if the endoscopic adhesiolysis was clinically relevant and effec- 
Table 1. Modified quality of evidence developed by USPSTF.

\begin{tabular}{|l|l||}
\hline \hline I: & Evidence obtained from at least one properly randomized controlled trial \\
\hline II-1: & Evidence obtained from well-designed controlled trials without randomization \\
\hline II-2: & $\begin{array}{l}\text { Evidence obtained from well-designed cohort or case-control analytic studies, preferably from more than one center or research } \\
\text { group }\end{array}$ \\
\hline II-3: & $\begin{array}{l}\text { Evidence obtained from multiple time series with or without the intervention. Dramatic results in uncontrolled experiments (such } \\
\text { as the results of the introduction of penicillin treatment in the 1940s) could also be regarded as this type of evidence }\end{array}$ \\
\hline III: & Opinions of respected authorities, based on clinical experience descriptive studies and case reports or reports of expert committees \\
\hline
\end{tabular}

Adapted and modified from the U.S. Preventive Services Task Force (USPSTF) (92).

Table 2. Grading recommendations.

\begin{tabular}{|c|c|c|c|}
\hline $\begin{array}{c}\text { Grade of Recommendation/ } \\
\text { Description }\end{array}$ & Benefit vs Risk and Burdens & $\begin{array}{l}\text { Methodological Quality of } \\
\text { Supporting Evidence }\end{array}$ & Implications \\
\hline $\begin{array}{l}1 \mathrm{~A} / \text { strong recommendation, } \\
\text { high-quality evidence }\end{array}$ & $\begin{array}{l}\text { Benefits clearly outweigh risk } \\
\text { and burdens, or vice versa }\end{array}$ & $\begin{array}{l}\text { RCTs without important limitations } \\
\text { or overwhelming evidence from } \\
\text { observational studies }\end{array}$ & $\begin{array}{l}\text { Strong recommendation, } \\
\text { can apply to most patients in } \\
\text { most circumstances without } \\
\text { reservation }\end{array}$ \\
\hline $\begin{array}{l}1 \mathrm{~B} / \text { strong recommendation, } \\
\text { moderate quality evidence }\end{array}$ & $\begin{array}{l}\text { Benefits clearly outweigh risk } \\
\text { and burdens, or vice versa }\end{array}$ & $\begin{array}{l}\text { RCTs with important limitations } \\
\text { (inconsistent results, methodologi- } \\
\text { cal flaws, indirect, or imprecise) or } \\
\text { exceptionally strong evidence from } \\
\text { observational studies }\end{array}$ & $\begin{array}{l}\text { Strong recommendation, } \\
\text { can apply to most patients in } \\
\text { most circumstances without } \\
\text { reservation }\end{array}$ \\
\hline $\begin{array}{l}1 \mathrm{C} / \text { strong recommendation, } \\
\text { low-quality or very low-quality } \\
\text { evidence }\end{array}$ & $\begin{array}{l}\text { Benefits clearly outweigh risk } \\
\text { and burdens, or vice versa }\end{array}$ & Observational studies or case series & $\begin{array}{l}\text { Strong recommendation but } \\
\text { may change when higher qual- } \\
\text { ity evidence becomes available }\end{array}$ \\
\hline $\begin{array}{l}\text { 2A/weak recommendation, high- } \\
\text { quality evidence }\end{array}$ & $\begin{array}{l}\text { Benefits closely balanced with } \\
\text { risks and burden }\end{array}$ & $\begin{array}{l}\text { RCTs without important limitations } \\
\text { or overwhelming evidence from } \\
\text { observational studies }\end{array}$ & $\begin{array}{l}\text { Weak recommendation, best } \\
\text { action may differ depending } \\
\text { on circumstances or patients' } \\
\text { or societal values }\end{array}$ \\
\hline $\begin{array}{l}2 \mathrm{~B} / \text { weak recommendation, mod- } \\
\text { erate-quality evidence }\end{array}$ & $\begin{array}{l}\text { Benefits closely balanced with } \\
\text { risks and burden }\end{array}$ & $\begin{array}{l}\text { RCTs with important limitations } \\
\text { (inconsistent results, methodologi- } \\
\text { cal flaws, indirect, or imprecise) or } \\
\text { exceptionally strong evidence from } \\
\text { observational studies }\end{array}$ & $\begin{array}{l}\text { Weak recommendation, best } \\
\text { action may differ depending } \\
\text { on circumstances or patients' } \\
\text { or societal values }\end{array}$ \\
\hline $\begin{array}{l}2 \mathrm{C} / \text { weak recommendation, } \\
\text { low-quality or very low-quality } \\
\text { evidence }\end{array}$ & $\begin{array}{l}\text { Uncertainty in the estimates } \\
\text { of benefits, risks, and burden; } \\
\text { benefits, risk, and burden may be } \\
\text { closely balanced }\end{array}$ & Observational studies or case series & $\begin{array}{l}\text { Very weak recommendations; } \\
\text { other alternatives may be } \\
\text { equally reasonable }\end{array}$ \\
\hline
\end{tabular}

Adapted from Guyatt $\mathrm{G}$ et al. Grading strength of recommendations and quality of evidence in clinical guidelines. Report from an American College of Chest Physicians task force. Chest 2006; 129:174-181 (93).

tive, either with a placebo control or active control in randomized trials. This indicates that the difference in the effect for the primary outcome measure was statistically significant at the conventional $5 \%$ level. In a negative study, no difference between the study treatment or no improvement from baseline was reported. Further, the outcomes were judged at the ref- erence point with positive or negative results reported at 3 months, 6 months, and one year.

For observational studies, a study was judged to be positive if the endoscopic adhesiolysis was effective, with outcomes reported at the references point with positive or negative results at 3 months, 6 months, and one year. 


\section{Results}

A literature search was carried out for endoscopic adhesiolysis as shown in Fig. 1.

Our search strategy yielded multiple studies evaluating the effectiveness of endoscopic adhesiolysis that were considered for inclusion. These included 2 systematic reviews $(69,70)$ and 13 studies $(67,94-105)$. Of these, there were 3 randomized trials $(67,96,98)$, and 11 observational studies (94,95,97,99-106).

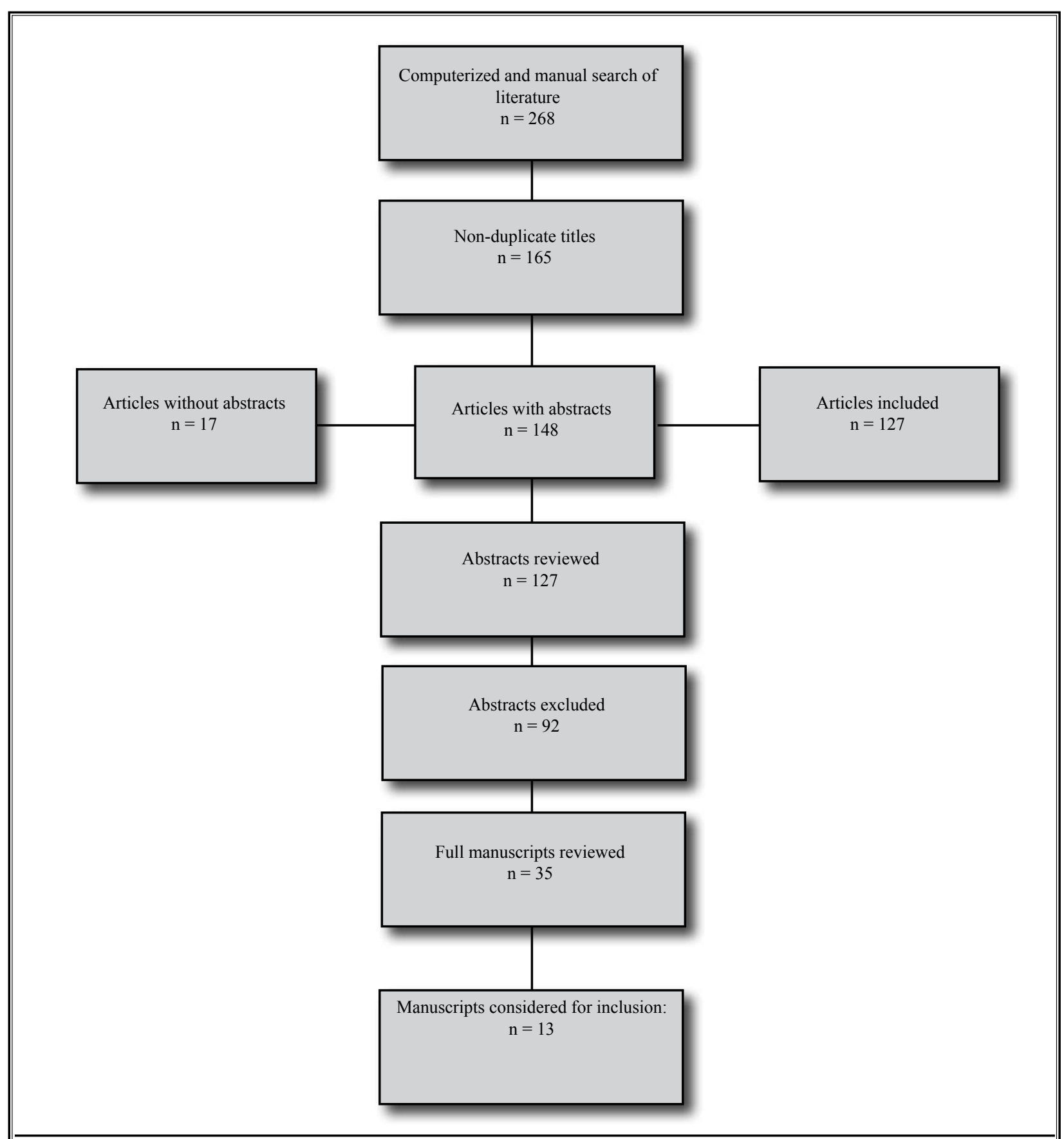

Fig. 1. The flow diagram illustrating available literature of endoscopic adhesiolysis. 


\section{Randomized Trials}

\section{Methodologic Quality Assessment}

Of the 3 randomized trials $(67,96,98)$, one was a preliminary report (96). The study by Dashfield et al (98) evaluated patients without surgical intervention and without prior treatment with fluoroscopically directed epidural injections. The indications for spinal endoscopic adhesiolysis in this study were flawed. Thus, it was excluded from methodologic quality assessment.

The sole randomized trial (67) that met the inclusion criteria had a heterogenous population.

Methodologic quality assessment criteria of the one study meeting inclusion criteria are illustrated in Table 3. The quality assessment criteria was 69 .

\section{Clinical Relevance Assessment}

Table 4 illustrates the clinical relevance of the randomized trial.

\section{Study Characteristics}

Manchikanti et al (67) evaluated the effectiveness of spinal endoscopic adhesiolysis in chronic refractory low back and lower extremity pain in a randomized controlled trial. However, this trial was not a placebocontrol, but was a randomized, double blind, equivalence or non-inferiority trial utilizing an active control design. These studies are common in interventional pain management and are considered to be ideal (6365,87-91,107-114). In this study, a total of 83 patients were evaluated, with 33 patients in Group I and 50 pa-

Table 3. Methodological assessment of randomized clinical trials of therapeutic of spinal endoscopic adhesiolysis.

\begin{tabular}{|c|c|c|c|}
\hline \multicolumn{2}{|r|}{ CRITERION } & $\begin{array}{l}\text { WEIGHTED SCORE } \\
\text { (points) }\end{array}$ & $\begin{array}{c}\text { Manchikanti et al } \\
(67)\end{array}$ \\
\hline \multicolumn{2}{|c|}{ 1. Study population } & 35 & 14 \\
\hline A & Homogeneity & 2 & 2 \\
\hline $\mathrm{B}$ & Comparability of relevant baseline characteristics & 5 & 5 \\
\hline $\mathrm{C}$ & Randomization procedure adequate & 4 & 4 \\
\hline $\mathrm{D}$ & Drop-outs described for each study group separately & 3 & 3 \\
\hline \multirow[t]{2}{*}{$\mathrm{E}$} & $<20 \%$ loss for follow-up & 2 & 0 \\
\hline & $<10 \%$ loss for follow-up & 2 & 0 \\
\hline \multirow[t]{2}{*}{$\mathrm{F}$} & $>50$ subject in the smallest group & 8 & 0 \\
\hline & $>100$ subjects in the smallest group & 9 & 0 \\
\hline \multicolumn{2}{|c|}{ 2. Interventions } & 25 & 15 \\
\hline G & Interventions included in protocol and described & 10 & 10 \\
\hline $\mathrm{H}$ & Pragmatic study & 5 & 5 \\
\hline I & Co-interventions avoided or similar & 5 & 0 \\
\hline $\mathrm{J}$ & Placebo-controlled & 5 & 0 \\
\hline \multicolumn{2}{|c|}{ 3. Effect } & 30 & 30 \\
\hline $\mathrm{K}$ & Patients blinded & 5 & 5 \\
\hline $\mathrm{L}$ & Outcome measures relevant & 10 & 10 \\
\hline M & Blinded outcome assessments & 10 & 10 \\
\hline $\mathrm{N}$ & Follow-up period adequate & 5 & 5 \\
\hline \multicolumn{2}{|c|}{ 4. Data-presentation and analysis } & 10 & 10 \\
\hline $\mathrm{O}$ & Intention-to-treat analysis & 5 & 5 \\
\hline $\mathrm{P}$ & $\begin{array}{l}\text { Frequencies of most important outcomes presented for each treatment } \\
\text { group }\end{array}$ & 5 & 5 \\
\hline & TOTAL SCORE & 100 & 69 \\
\hline
\end{tabular}

Methodological criteria and scoring adapted from Koes BW et al. Efficacy of epidural steroid injections for low-back pain and sciatica: A systematic review of randomized clinical trials. Pain 1995; 63:279-288 (72). 
Table 4. Clinical relevance of randomized clinical trials evaluating the effectiveness of spinal endoscopic adhesiolysis.

\begin{tabular}{|l|c||}
\hline & Manchikanti et al (67) \\
\hline $\begin{array}{l}\text { A) Are the patients described in detail so that you can decide whether they are comparable to those that you see } \\
\text { in your practice? }\end{array}$ & + \\
\hline $\begin{array}{l}\text { B) Are the interventions and treatment settings described well enough so that you can provide the same for your } \\
\text { patients? }\end{array}$ & + \\
\hline C) Were all clinically relevant outcomes measured and reported? & + \\
\hline D) Is the size of the effect clinically important? & + \\
\hline E) Are the likely treatment benefits worth the potential harms? & + \\
\hline
\end{tabular}

+ = positive; - = negative

Scoring adapted from Staal JB et al. Injection therapy for subacute and chronic low-back pain. Cochrane Database Syst Rev 2008; 3:CD001824 (60).

tients in Group II. Group I served as an active control, with endoscopy into the sacral level without adhesiolysis, followed by injection of local anesthetic and steroid. In contrast, Group II received spinal endoscopic adhesiolysis, followed by an injection of local anesthetic and steroid. Among the 50 patients in the treatment group receiving spinal endoscopic adhesiolysis, significant improvement without adverse effects were shown in $80 \%$ at 2 months, $56 \%$ at 6 months, and $48 \%$ at 12 months. The control group showed improvement in $33 \%$ of patients at one month and none thereafter. Based on the definition that less than 6 months of relief is considered short-term and longer than 6 months of relief is considered long-term, a significant number of patients obtained long-term relief with improvement in pain, functional status, and psychological status. In this study, the authors performed an intentionto-treat analysis. Outcome assessments included visual analog pain scale (VAS), Oswestry Disability Index 2.0 (ODI), work status, opioid intake, range of motion, and psychological evaluation.

The disadvantages of this study include lack of a placebo group; however, placebo control may never be achieved for an intervention such as spinal endoscopic adhesiolysis. The study met methodologic quality assessment and also had 50 patients in the treatment group while there were less than 50 patients in the control group.

\section{Observational Studies}

\section{Methodologic Quality Assessment}

There were 10 observational studies considered for inclusion $(94,95,97,99-105)$. Of the 10 studies, 5 met criteria for inclusion for methodologic quality assessment $(97,99,101,103,104)$. Methodologic quality assessment criteria are illustrated in Table 5. Methodologic quality assessment showed scores of 53 to 77. Five studies failed to meet the inclusion criteria: One study (100) evaluated the role of endoscopic adhesiolysis in refractory spinal stenosis; the second study (95) evaluated the effectiveness of endoscopic adhesiolysis in radiculitis; 2 studies $(94,102)$ evaluated short-term improvement; and one study (105) was a technical description.

Table 6 illustrates the study characteristics of observational studies.

\section{Descriptive Characteristics}

Some studies reported on the proportion of patients with lumbar post-laminectomy syndrome or FBSS $(67,97,99,101,103,104)$. Among those studies, the percentage of patients with FBSS varied with the study from $50 \%(101)$ to $100 \%(97,103)$. The patients had failed conservative medical management prior to enrolling in all the studies. In the studies by Manchikanti et al $(67,103,104)$, the investigators had additionally ruled out facet and sacroiliac joint pain, important sources of low back pain, prior to enrolling patients. Outcomes measured included, in addition to pain scores, functional outcomes, psychological status, opioid intake, and return to work.

Effectiveness of spinal endoscopic adhesiolysis was investigated based on the following questions:

$1 \mathrm{~A}$. Is spinal endoscopic adhesiolysis with or without steroids effective in treating low back and/or radicular pain in patients with and without FBSS? 
Pain Physician: March/April 2009:12:419-435

Table 5. Methodologic quality assessment criteria for observational studies of spinal endoscopic adhesiolysis.

\begin{tabular}{|c|c|c|c|c|c|c|}
\hline CRITERION & $\begin{array}{c}\text { Weighted } \\
\text { Score } \\
\text { (points) } \\
\end{array}$ & $\begin{array}{c}\text { Manchikanti } \\
\text { et al (103) }\end{array}$ & $\begin{array}{c}\text { Manchikanti } \\
\text { et al (104) }\end{array}$ & $\begin{array}{l}\text { Richardson } \\
\text { et al (101) }\end{array}$ & $\begin{array}{l}\text { Geurts } \\
\text { et al } \\
(99) \\
\end{array}$ & $\begin{array}{c}\text { Avellanal } \\
\text { and Diaz- } \\
\text { Reganon (97) }\end{array}$ \\
\hline 1. Study Question & 2 & 2 & 1 & 1 & 2 & 1 \\
\hline - Clearly focused and appropriate question & 2 & 2 & 1 & 1 & 2 & 1 \\
\hline 2. Study Population & 8 & 5 & 4 & 4 & 5 & 3 \\
\hline - Description of study population & 5 & 5 & 4 & 4 & 5 & 3 \\
\hline - Sample size justification & 3 & 0 & 0 & 0 & 0 & 0 \\
\hline 3. Comparability of Subjects & 22 & 12 & 11 & 12 & 14 & 14 \\
\hline - Specific inclusion/exclusion criteria for all groups & 5 & 4 & 5 & 5 & 5 & 5 \\
\hline - Criteria applied equally to all groups & 3 & 3 & 2 & 3 & 3 & 3 \\
\hline $\begin{array}{l}\text { - Comparability of groups at baseline with } \\
\text { regard to disease status and prognostic factors }\end{array}$ & 3 & 2 & 2 & 1 & 3 & 3 \\
\hline $\begin{array}{l}\text { - Study groups comparable to non-participants } \\
\text { with regard to confounding factors }\end{array}$ & 3 & 0 & 0 & 0 & 0 & 0 \\
\hline - Use of concurrent controls & 5 & 0 & 0 & 0 & 0 & 0 \\
\hline $\begin{array}{l}\text { - Comparability of follow-up among groups at } \\
\text { each assessment }\end{array}$ & 3 & 3 & 2 & 3 & 3 & 3 \\
\hline 4. Exposure or Intervention & 11 & 10 & 9 & 11 & 10 & 10 \\
\hline - Clear definition of exposure & 5 & 5 & 5 & 5 & 5 & 5 \\
\hline - Measurement method standard, valid and reliable & 3 & 2 & 1 & 3 & 2 & 2 \\
\hline - Exposure measured equally in all study groups & 3 & 3 & 3 & 3 & 3 & 3 \\
\hline 5. Outcome measures & 20 & 10 & 8 & 15 & 20 & 11 \\
\hline - Primary/secondary outcomes clearly defined & 5 & 4 & 3 & 5 & 5 & 3 \\
\hline $\begin{array}{l}\text { - Outcomes assessed blind to exposure or } \\
\text { intervention }\end{array}$ & 5 & 0 & 0 & 0 & 5 & 0 \\
\hline $\begin{array}{l}\text { - Method of outcome assessment standard, } \\
\text { valid and reliable }\end{array}$ & 5 & 1 & 0 & 5 & 5 & 4 \\
\hline - Length of follow-up adequate for question & 5 & 5 & 5 & 5 & 5 & 4 \\
\hline 6. Statistical Analysis & 19 & 10 & 14 & 10 & 8 & 5 \\
\hline - Statistical tests appropriate & 5 & 5 & 5 & 5 & 5 & 5 \\
\hline - Multiple comparisons taken into consideration & 3 & 3 & 3 & 3 & 0 & 0 \\
\hline $\begin{array}{l}\text { - Modeling and multivariate techniques } \\
\text { appropriate }\end{array}$ & 2 & 2 & 0 & 2 & 1 & 0 \\
\hline - Power calculation provided & 2 & 0 & 0 & 0 & 2 & 0 \\
\hline - Assessment of confounding & 5 & 0 & 5 & 0 & 0 & 0 \\
\hline - Dose-response assessment if appropriate & 2 & 0 & 1 & 0 & 0 & 0 \\
\hline 7. Results & 8 & 8 & 7 & 8 & 8 & 6 \\
\hline $\begin{array}{l}\text { - Measure of effect for outcomes and appropri- } \\
\text { ate measure of precision }\end{array}$ & 5 & 5 & 4 & 5 & 5 & 4 \\
\hline - Adequacy of follow-up for each study group & 3 & 3 & 3 & 3 & 3 & 2 \\
\hline 8. Discussion & 5 & 5 & 4 & 5 & 5 & 3 \\
\hline $\begin{array}{l}\text { - Conclusions supported by results with possible } \\
\text { biases and limitations taken into consideration }\end{array}$ & 5 & 5 & 4 & 5 & 5 & 3 \\
\hline 9. Funding or Sponsorship & 5 & 0 & 0 & 0 & 5 & 0 \\
\hline - Type and sources of support for study & 5 & 0 & 0 & 0 & 5 & 0 \\
\hline TOTAL SCORE $=$ & 100 & 62 & 58 & 66 & 77 & 53 \\
\hline
\end{tabular}

Adapted and modified from West S et al. Systems to Rate the Strength of Scientific Evidence, Evidence Report, Technology Assessment No. 47. AHRQ Publication No. 02-E016 (71). 
Table 6. Summary description of observational studies for spinal endoscopic adhesiolysis.

\begin{tabular}{|c|c|c|c|c|c|c|}
\hline $\begin{array}{l}\text { Study I } \\
\text { Methods }\end{array}$ & Participants & Intervention & Outcome & Results & $\begin{array}{c}\text { Conclusion(s) } \\
\text { Short-term } \leq 6 \\
\text { mos. } \\
\text { Long-term }>6 \\
\text { mos. }\end{array}$ & Complications \\
\hline $\begin{array}{l}\text { Manchikanti } \\
\text { et al } 1999 \\
(103)\end{array}$ & $\begin{array}{l}60 \text { FBSS patients } \\
\text { - excluded facet } \\
\text { and SI joint pain }\end{array}$ & $\begin{array}{l}\text { Epiduroscope to } \\
\text { level of pathology, } \\
\text { adhesiolysis, } 10 \\
\text { mL } 1 \% \text { lidocaine + } \\
\text { steroid injection }\end{array}$ & $\begin{array}{l}\text { Pain relief: } \\
\text { 1) none } \\
\text { 2) }<50 \% \\
\text { 3) } 50 \% \\
\text { (successful) } \\
\text { Duration: }<1 \\
\text { month, } 1,2,3,6 \text {, } \\
\text { and } 12 \text { months }\end{array}$ & $\begin{array}{l}\text { Initial success (> } \\
50 \% \text { relief) in } 100 \% \\
\text { of patients declining } \\
\text { to } 80 \% \text { at } 3 \text { months, } \\
52 \% \text { at } 6 \text { months, and } \\
22 \% \text { at one year }\end{array}$ & $\begin{array}{l}\text { Safe and possibly } \\
\text { cost effective } \\
\text { procedure in pa- } \\
\text { tients with FBSS } \\
\text { (long-term) }\end{array}$ & $\begin{array}{l}\text { Dural puncture in } 7 \\
\text { procedures. } \\
\text { "Suspected" infec- } \\
\text { tion in } 8 \text { patients } \\
\text { who were given } \\
\text { antibiotics but no } \\
\text { "obvious" infection } \\
\text { was noted }\end{array}$ \\
\hline $\begin{array}{l}\text { Manchikanti } \\
\text { et al } 2000 \\
(104)\end{array}$ & $\begin{array}{l}85 \text { consecutive } \\
\text { patients ( } 86 \% \\
\text { with FBSS) } \\
\text { underwent } \\
112 \text { epiduros- } \\
\text { copic adhesiolysis } \\
\text { procedures ( } 27 \\
\text { patients had a } \\
\text { second proce- } \\
\text { dure). Follow up } \\
\text { for } 1-2 \text { years }\end{array}$ & $\begin{array}{l}\text { Epiduroscopic } \\
\text { adhesiolysis and } \\
\text { application of } 10 \mathrm{~mL} \\
1 \% \text { lidocaine }+6 \mathrm{mg} \\
\text { betamethasone }\end{array}$ & $\begin{array}{l}\text { Pain relief: } \\
\text { 1) none } \\
\text { 2) }<50 \% \\
\text { 3) }>50 \% \\
\text { (significant) } \\
\text { Duration: }<1 \\
\text { month, } 1,2,3,6 \text {, } \\
\text { and } 12 \text { months }\end{array}$ & $\begin{array}{l}\text { Significant }(>50 \%) \\
\text { relief for a mean of } 19 \\
\pm 1.79 \text { weeks. After } \\
\text { one procedure, initial } \\
\text { relief in } 100 \% \text { of } \\
\text { patients, declined to } \\
94 \% \text { at } 1-2 \text { months, } \\
77 \% \text { at } 2-3 \text { months, } \\
52 \% \text { at } 3-6 \text { months, } \\
21 \% \text { at } 6-12 \text { months, } \\
\text { and } 7 \% \text { after one year }\end{array}$ & $\begin{array}{l}\text { Relatively safe } \\
\text { and possibly cost } \\
\text { effective proce- } \\
\text { dure in patients } \\
\text { who have failed } \\
\text { other modali- } \\
\text { ties of treatment } \\
\text { (long-term) }\end{array}$ & $\begin{array}{l}\text { Dural puncture in } 8 \\
\text { patients. Subarach- } \\
\text { noid block in } 4 \text { pa- } \\
\text { tients. } 2 \text { documented } \\
\text { infections (one } \\
\text { requiring skin graft- } \\
\text { ing and prolonged } \\
\text { antibiotics) and } \\
6 \text { "SUSPECTED" } \\
\text { infections. }\end{array}$ \\
\hline $\begin{array}{l}\text { Richardson } \\
\text { et al 2001 } \\
(101)\end{array}$ & $\begin{array}{l}38 \text { patients with } \\
\text { lumbar radicular } \\
\text { pain who failed } \\
\text { analgesics, TENS, } \\
\text { and epidural } \\
\text { injections were } \\
\text { recruited; } 19 \text { had } \\
\text { FBSS. Procedure. } \\
\text { Aborted in } 4 \\
\text { patients }\end{array}$ & $\begin{array}{l}34 \text { patients under- } \\
\text { went mechanical } \\
\text { adhesiolysis }+5 \mathrm{~mL} \\
\text { bupivacaine } 0.25 \%+ \\
80 \mathrm{mg} \text { methyl-pred- } \\
\text { nisolone }+100 \mathrm{mcg} \\
\text { clonidine. }\end{array}$ & $\begin{array}{l}\text { VAS + func- } \\
\text { tional activity } \\
\text { score at } 2,6 \text {, and } \\
12 \text { months post } \\
\text { procedure }\end{array}$ & $\begin{array}{l}\text { Preoperative VAS } 8.2 \\
\rightarrow 5.6,6.8 \text {, and } 6.7 \text { at } \\
2,6 \text {, and } 12 \text { months } \\
\text { respectively. A } \\
\text { similarly significant } \\
\text { functional improve- } \\
\text { ment was noted }\end{array}$ & $\begin{array}{l}\text { Epiduroscopic } \\
\text { adhesiolysis } \\
\text { achieved moder- } \\
\text { ate but sustained } \\
\text { reduction in } \\
\text { chronic lumbar } \\
\text { radicular pain as } \\
\text { well as improve- } \\
\text { ment in func- } \\
\text { tional status }\end{array}$ & $\begin{array}{l}\text { Transient low back } \\
\text { pain in some and } \\
\text { transient lower } \\
\text { limb paresthesiae } \\
\text { in } 2 \text { patients. None } \\
\text { required hospital } \\
\text { admission. }\end{array}$ \\
\hline $\begin{array}{l}\text { Geurts et al } \\
2002(99)\end{array}$ & $\begin{array}{l}24 \text { patients were } \\
\text { recruited: radicu- } \\
\text { lar pain below } \\
\text { knee + evidence } \\
\text { of radiculopathy } \\
\text { by exam; leg pain } \\
\text { > back pain } \\
2 \text { patients unable } \\
\text { to enter caudal } \\
\text { space (excluded); } \\
14 \text { of the remain- } \\
\text { ing } 22 \text { were FBSS } \\
\text { patients }\end{array}$ & $\begin{array}{l}\text { Mechanical } \\
\text { adhesiolysis }+120 \\
\text { mg methyl-pred- } \\
\text { nisolone }+600 \mathrm{IU} \\
\text { hyaluronidase }+150 \\
\text { mcg clonidine. } \\
2 \text { patients had no } \\
\text { injection and were } \\
\text { excluded: one with } \\
\text { no adhesions and } \\
\text { another because of } \\
\text { dural puncture }\end{array}$ & $\begin{array}{l}\text { Median VAS } \\
\text { score from } 12 \\
\text { recordings over } \\
\text { a } 4 \text { day period } \\
\text { one week before } \\
\text { intervention } \\
\text { and assessment } \\
\text { at } 3,6,9 \text { and } 12 \\
\text { months. Global } \\
\text { subjective } \\
\text { efficacy rating } \\
\text { (GSER) at } 12 \\
\text { months. }\end{array}$ & $\begin{array}{l}19 / 20 \text { patients } \\
\text { showed adhesions } \\
\text { by epiduroscopy vs. } \\
11 / 20 \text { by MRI } \\
\text { Significant pain } \\
\text { relief at } 3,6,9 \text {, and } \\
12 \text { months occurred } \\
\text { in } 55 \%, 40 \%, 35 \% \\
\text { and } 35 \% \text { of patients } \\
\text { respectively Similar } \\
\text { findings by GSER at } \\
12 \text { months }\end{array}$ & $\begin{array}{l}\text { Epiduroscopy is } \\
\text { useful in diagnos- } \\
\text { ing spinal root } \\
\text { pathology and } \\
\text { targeted applica- } \\
\text { tion of epidu- } \\
\text { ral medications } \\
\text { can result in } \\
\text { substantial and } \\
\text { prolonged pain } \\
\text { relief }\end{array}$ & $\begin{array}{l}\text { One accidental dural } \\
\text { puncture noted; pro- } \\
\text { cedure aborted and } \\
\text { patient was excluded } \\
\text { from analysis. How- } \\
\text { ever, } 3 \text { patients had } \\
\text { post-dural puncture } \\
\text { headache and } 2 \\
\text { required epidural } \\
\text { blood patches. } \\
\text { Transient intra-op- } \\
\text { erative discomfort in } \\
\text { some patients. }\end{array}$ \\
\hline \begin{tabular}{|l} 
Avellanal and \\
Diaz-Re- \\
ganon 2008 \\
$(97)$
\end{tabular} & $\begin{array}{l}19 \text { patients with h/ } \\
\text { o FBSS and severe } \\
\text { sciatica (VAS } \geq 7 \text { ) } \\
\text { who have failed } \\
\text { multiple treatment } \\
\text { modalities includ- } \\
\text { ing adhesiolysis } \\
\text { with a Racz cath- } \\
\text { eter. All patients } \\
\text { had X-rays, MRI, } \\
\text { and EMG within } \\
2 \text { months of } \\
\text { enrollment }\end{array}$ & $\begin{array}{l}\text { Interlaminar epidur- } \\
\text { oscopic adhesiolysis } \\
\text { at L5/S1 and oc- } \\
\text { casionally at L4/L5 } \\
\text { or L3/L4. } \\
6 \mathrm{~mL} \text { mixture of tri- } \\
\text { amcinolone, } 40 \mathrm{mg} \text {, } \\
\text { hyaluronidase } 600 \\
\mathrm{IU} \text {, and bupivacaine } \\
0.0625 \% \text { was } \\
\text { injected }\end{array}$ & $\begin{array}{l}\text { VAS at } 1,2,3 \text {, } \\
\text { and } 6 \text { months. }\end{array}$ & $\begin{array}{l}\text { Compared to VAS at } \\
\text { baseline, there was } \\
\text { significant reduc- } \\
\text { tion in pain at } 1,2 \text {, } \\
3 \text {, and } 6 \text { months. } \\
\text { Six patients had no } \\
\text { improvement at } 3 \\
\text { months or later, } 7 \\
\text { experienced mild } \\
\text { improvement, and } 6 \\
\text { improved markedly } \\
\text { (> } 3 \text { points on the } \\
\text { VAS) }\end{array}$ & $\begin{array}{l}\text { A } 50 \% \text { smaller } \\
\text { diameter } \\
\text { endoscope is ef- } \\
\text { fective in pain } \\
\text { relief through } \\
\text { adhesiolysis in } \\
\text { patients with } \\
\text { FBSS }\end{array}$ & $\begin{array}{l}4 \text { dural punctures } \\
\text { (21\%), one neces- } \\
\text { sitating admission } \\
\text { to the hospital for } \\
5 \text { days; transient } \\
\text { headache and hypo- } \\
\text { tension during the } \\
\text { procedure lasting } \\
<30 \text { sec; some low } \\
\text { back and leg pain re- } \\
\text { lieved spontaneously } \\
\text { within } 2 \text { days }\end{array}$ \\
\hline
\end{tabular}


There were no placebo controlled trials of spinal endoscopic adhesiolysis. However, in the double blind randomized controlled trial by Manchikanti et al (67), patients were included in the study if they had refractory low back pain and lower extremity pain and had failed to have significant response with fluoroscopically guided caudal epidural steroid injections and one-day percutaneous adhesiolysis. Lack of significant response to caudal epidural steroid injections was defined as $\geq 50 \%$ pain relief for $\leq$ one week after a second epidural steroid injection and $\geq 50 \%$ pain relief for $\leq 4$ weeks after a third epidural steroid injection. Lack of significant response to one-day percutaneous non-endoscopic adhesiolysis was defined as no response to the first adhesiolysis procedure and less than 2 months of pain relief ( $\geq 50 \%$ ) following the second or subsequent procedures. Other causes of low back pain such as facet and sacroiliac joint pain were ruled out by diagnostic blocks prior to the patients enrolling in the study. Patients were randomized to spinal endoscopic adhesiolysis or caudal epidural steroid injections once the endoscope reached the level of S3 by fluoroscopy (hence considered to be a control group). Among patients enrolled, $73 \%$ in the group randomized to caudal epidural steroid injections had FBSS compared to $84 \%$ of the patients randomized to spinal endoscopic adhesiolysis. While data were not stratified according to patients having a history of FBSS or having back vs. leg pain, there was a very significant increase in the duration of pain relief in the spinal endoscopic adhesiolysis group (with targeted steroid injection) compared to the caudal epidural steroid injection group $(P=0.001)$ using an intent-to-treat analysis (67). Similarly, there were significant improvements in the functional and psychological status of patients.

The prospective observational study by Geurts et al (99) recruited patients who had predominantly radicular leg pain. About two-thirds of the patients who underwent spinal endoscopic adhesiolysis had FBSS. Spinal endoscopic adhesiolysis with targeted steroid, hyaluronidase, and clonidine deposition resulted in significant pain relief and an improved Global Subjective Efficacy Rating (GSER) in a significant number of patients at 3, 6, 9 , and 12 months after the intervention. Similarly, significant pain relief and functional improvement were noted in the study by Richardson et al (101) where the recruited patients had leg and chronic low back pain. All patients had failed transcutaneous nerve stimulation and $50 \%$ of the patients had FBSS. Unfortunately, neither study stratified patients based on a history of FBSS $(99,101)$.

In an earlier observational study by Manchikanti et al (103), 60 consecutive patients with FBSS underwent spinal endoscopic adhesiolysis in 1998. They were compared to 60 consecutive patients with FBSS who underwent non-endoscopic percutaneous adhesiolysis in 1997. The patients had to have failed additional intervening conservative medical management including epidural steroid injections, and other causes of low back pain including facet joint pain and sacroiliac joint pain were excluded. Significant pain relief was defined as greater than $50 \%$ pain relief. All patients undergoing either procedure had initial significant pain relief after one procedure which declined to $72 \%$ at one month, $25 \%$ at 3 months, $10 \%$ at 6 months, and $7 \%$ at one year for the non-endoscopic adhesiolysis group and $97 \%$ at one month, $80 \%$ at 3 months, $52 \%$ at 6 months, and $22 \%$ at one year for the spinal endoscopy group. Duration of pain relief with the first procedure was $12 \pm 3.6$ weeks for non-endoscopic adhesiolysis compared to $20 \pm 2.9$ weeks for the endoscopic adhesiolysis group. However, patients in the non-endoscopic group received more repeat procedures than the endoscopic group. With repeat procedures a significantly greater number of patients had significant pain relief at 6 months and one year in the non-endoscopic adhesiolysis group compared to the endoscopic adhesiolysis group (103).

B. In patients with chronic low back and lumbar radicular pain is spinal endoscopic adhesiolysis effective in providing longer duration of symptom relief as compared to placebo or another treatment (such as percutaneous adhesiolysis without endoscopy or caudal epidural steroid injection) and does it improve outcomes?

The double blind placebo controlled study by Manchikanti et al (67) randomized patients to endoscopic adhesiolysis at target nerve roots or to introduction of the epiduroscope to only S3 and performed a caudal epidural steroid injection 
(control group). Compared to the control group and to baseline values, a significant proportion of patients in the spinal endoscopic adhesiolysis group experienced pain relief. The duration of significant pain relief ( $\geq 50 \%$ ) was $0.7 \pm 0.73$ months for the caudal group vs. $7.6 \pm 4.7$ months for the spinal endoscopic adhesiolysis group. Similar significant functional improvements were noted in the ODI and in range of motion evaluations in the endoscopic adhesiolysis group compared to baseline and to the control group. Additionally, there were significant improvements in psychological outcomes of depression, anxiety, and somatization (P-3 scores), decreases in opioid consumption, and improved return to work rates in the endoscopic adhesiolysis group compared to the caudal group and to baseline (67). Of note, all patients recruited in this study had also failed non-endoscopic adhesiolysis. Manchikanti et al (103) also compared 60 consecutive patients with FBSS who underwent spinal endoscopic adhesiolysis in 1998 to 60 consecutive patients with FBSS who underwent non-endoscopic percutaneous adhesiolysis in 1997. Duration of pain relief after one procedure was longer for the spinal endoscopic adhesiolysis than the non-endoscopic adhesiolysis and a greater proportion of patients in the endoscopic group had pain relief than in the non-endoscopic group after one procedure. However, in this retrospective study, more patients in the non-endoscopic group received repeat procedures and as such a greater proportion of those patients had significant pain relief compared to the endoscopic group at 6 months and at one-year timelines after adhesiolysis (103).

Avellanal and Diaz-Reganon (97) using an interlaminar endoscopic adhesiolysis approach in an observational study of 19 patients with FBSS who had failed non-endoscopic adhesiolysis reported significant improvements in VAS scores at one, 2, 3 , and 6 months after the intervention.

2. What is the role of medications used with spinal endoscopic adhesiolysis?

Local anesthetic and glucocorticoid steroid application occurred following mechanical spinal endoscopic adhesiolysis in all studies included in the analysis in this systematic review. Clonidine (100 mcg) was additionally used by Richardson et al (101), bovine hyaluronidase (600 IU) by Avellanal and Diaz-Reganon (97), and clonidine $(150 \mathrm{mcg})$ + bovine hyaluronidase (600 IU) were added to the local anesthetics/steroids by Geurts et al (99). There were no comparative studies evaluating the effectiveness of mechanical adhesiolysis alone to that of adhesiolysis with application of local anesthetics/steroids or evaluating the effectiveness of additional or adjuvant medications.

The previous evaluations of use of hyaluronidase showed no significant effect $(64,65)$. There is no significant evidence describing the utilization of hyaluronidase in spinal endoscopic adhesiolysis (99). In an experimental evaluation of hyaluronidase activity in combination with specific drugs applied in clinical techniques of interventional pain management and local anesthesia (115), the results showed that there was interaction among the drugs which was related to the activity of hyaluronidase with iodinated contrast media, 10\% sodium chloride solution, and the absence of corticosteroids reducing hyaluronidase activity. However, higher activities were detected in sodium chloride concentrations of $0.9 \%$ with no influence noted with local anesthetics.

3. Is spinal endoscopic adhesiolysis safe?

Common complications reported following spinal endoscopic adhesiolysis include pain at the site of the procedure/low back pain, dural puncture headache and cerebrospinal fluid (CSF) leak, infection, paresthesiae, and transient subarachnoid block. However, despite characterization of spinal endoscopic adhesiolysis as a generally safe procedure as noted in the efficacy studies reviewed in this article, several case reports describe serious potential complications $(116,117)$. Severe visual impairment following epiduroscopy has been reported $(116,117)$. Apparently, increases in CSF pressure due to bolus fluid injections during the procedure can result in retinal hemorrhage and blindness with recovery in only $79 \%$ of the cases as reported by Gill and Heavner (116) who reviewed 12 cases of visual impairment following epiduroscopy (3 cases) or epidural fluid injection. In another report, intravascular spread of contrast was detected by fluoroscopy during 2 cases of 
lumbosacral epiduroscopy (117). Withdrawing or manipulating the endoscope resulted in resolution of the vascular (likely venous) uptake without any negative consequences to the patients (117). Despite the technical difficulty of manipulating an endoscope in the spinal canal, there are no reports in the literature of permanent neurological damage or reports of epidural hematoma or meningitis.

\section{Effectiveness}

The single randomized trial evaluating endoscopic adhesiolysis (67) showed positive results for short- and long-term relief. Of the 5 observational studies meeting methodologic quality criteria $(97,99,101,103,104)$, all of them showed positive results for short-term improvement, whereas none of them were positive for long-term relief.

Table 7 illustrates results of effectiveness of endoscopic adhesiolysis.

\section{Level of Evidence}

The indicated level of evidence is II-1 or II-2 for short- and long-term relief for endoscopic adhesiolysis in post lumbar laminectomy syndrome, based on one randomized trial.

\section{Recommendations}

Based on Guyatt et al's grading strength of recom- mendations and quality of evidence in clinical guidelines, the recommendation is $1 \mathrm{C} /$ strong for endoscopic adhesiolysis in post lumbar laminectomy syndrome.

\section{Complications}

The most commonly reported complications of spinal endoscopic adhesiolysis were dural puncture, infection, increase in CSF, and steroid side effects $(67,69,94,95,97,99-104,116-118)$. Intravascular injection, vascular injury, cerebral vascular or pulmonary embolus, reaction to the steroids, hypertonic saline or hyaluronidase, visual impairment, death, and brain damage also may result. Side effects are related to the administration of steroids and are generally attributed to the chemistry or pharmacology of the steroids. However, therapeutic doses of epidural steroids in appropriate dosing were without complications $(119,120)$.

\section{Discussion}

The present systematic review of the literature of the effectiveness of spinal endoscopic adhesiolysis in managing chronic intractable pain of post surgery syndrome indicated evidence level II-1 or II-2 based on USPSTF criteria and one randomized trial with a recommendation of $1 \mathrm{C} /$ strong recommendation $(67,92,93)$. Even though this systematic review focused only on patients with post lumbar laminectomy syndrome, there was a paucity of evidence and a weak recommendation was obtained. However, the expansion of

Table 7. Summary results of eligible studies of endoscopic adhesiolysis included in this systematic review.

\begin{tabular}{|c|c|c|c|c|c|c|c|}
\hline \multirow{2}{*}{ Study } & \multirow{2}{*}{$\begin{array}{c}\text { Study } \\
\text { Characteristics }\end{array}$} & \multirow{2}{*}{$\begin{array}{l}\text { Methodological } \\
\text { Quality Scoring }\end{array}$} & \multirow{2}{*}{$\begin{array}{l}\text { Number of } \\
\text { Participants }\end{array}$} & \multicolumn{2}{|c|}{ Significant Pain Relief } & \multicolumn{2}{|c|}{ Results } \\
\hline & & & & $\leq 6 \mathrm{mos}$ & $>6$ mos. & $\begin{array}{l}\text { Short-term } \\
\leq 6 \text { mos. }\end{array}$ & $\begin{array}{l}\text { Long-term } \\
>6 \text { mos. }\end{array}$ \\
\hline $\begin{array}{l}\text { Manchikanti et al } \\
2005(67)\end{array}$ & RA,DB & 69 & 83 & $56 \% *$ & $48 \%{ }^{*}$ & $\mathrm{P}$ & $\mathrm{P}$ \\
\hline $\begin{array}{l}\text { Manchikanti et al } \\
1999(103)\end{array}$ & $\mathrm{O}$ & 62 & 60 & $52 \% *$ & $22 \%^{*}$ & $\mathrm{P}$ & $\mathrm{N}$ \\
\hline $\begin{array}{l}\text { Manchikanti et al } \\
2000(104)\end{array}$ & $\mathrm{O}$ & 58 & 85 & $\begin{array}{c}21 \%^{*} 6-12 \\
\text { mos. }\end{array}$ & $\begin{array}{c}7 \%^{*}>12 \\
\text { mos. }\end{array}$ & $\mathrm{P}$ & $\mathrm{N}$ \\
\hline $\begin{array}{l}\text { Richardson et al } \\
2001 \text { (101) }\end{array}$ & $\mathrm{O}$ & 67 & 38 & Yes & Yes & $\mathrm{P}$ & $\mathrm{N}$ \\
\hline $\begin{array}{l}\text { Geurts et al } 2002 \\
(99)\end{array}$ & $\mathrm{O}$ & 77 & 24 & Yes & Yes & $\mathrm{P}$ & $\mathrm{N}$ \\
\hline $\begin{array}{l}\text { Avellanal and Diaz- } \\
\text { Reganon } 2008 \text { (97) }\end{array}$ & $\mathrm{O}$ & 53 & 19 & Yes & $\mathrm{N} / \mathrm{A}$ & $\mathrm{P}$ & $\mathrm{N}$ \\
\hline
\end{tabular}

${ }^{*}$ Denotes percentage of patients with $>50 \%$ pain relief

$\mathrm{RA}=$ randomized $\mathrm{DB}=$ double blind $\mathrm{O}=$ observational; $\mathrm{P}=$ positive; $\mathrm{N}=$ negative; $\mathrm{N} / \mathrm{A}=$ not applicable. 
the definition of short-term relief to 6 months or less and long-term relief to longer than 6 months provides a robust measure.

Complications related to the procedure are usually minor and for the most part can be prevented with careful attention to technique. In patients with persistent low back and/or radicular pain, particularly after having had one or more previous lumbar spinal surgery(ies), spinal endoscopic adhesiolysis offers a reasonable option at pain relief and functional improvement. In patients with FBSS, repeat surgeries typically do not improve the outcome and spinal cord stimulation was found to be a superior modality to reoperation (121). There are, however, no comparative studies evaluating spinal cord stimulation versus spinal endoscopic adhesiolysis. In addition, spinal endoscopic adhesiolysis would be more cost-effective than repeat lumbar spine surgery $(103,104)$. A recent reassessment of evidence by Manchikanti et al (68) emphasized the importance of guidelines and the potential implications of appropriate systematic reviews $(122,123)$.

Selection criteria for spinal endoscopic adhesiolysis includes patients with chronic refractory low back and/or lumbar radicular pain who are suspected of having adhesions contributing to their symptoms. It is believed that adhesiolysis improves the nutrition and mobility of lumbar nerves and facilitates delivery of local anesthetics and steroids to their target areas at the nerve roots that is otherwise made impossible by the presence of adhesions $(36,100)$. In addition, Takeshima et al (106) showed that progressive epidural scarring after epidural adhesiolysis with re-adhesions around the nerve root is responsible for recurrent pain.

The primary author of this systematic review does not perform endoscopic adhesiolysis in his practice, decreasing the likelihood of bias. Future spinal endoscopic adhesiolysis studies are needed to optimize pa- tient selection and improve identification of patients that would benefit from this modality. Patient stratification is essential to identifying proper patient selection criteria. Additionally, studies specifically evaluating adjuvant medications may need to be carried out; a recombinant form of human hyaluronidase is now commercially available but has yet to be tested in spinal endoscopic adhesiolysis. Prospective comparative studies evaluating efficacy and cost effectiveness of spinal endoscopic adhesiolysis to non-endoscopic adhesiolysis or other interventional modalities such as spinal cord stimulation would be valuable and facilitate clinical decision-making.

\section{Conclusion}

Spinal adhesions appear to be an important contributor to refractory low back and/or lumbar radicular pain, especially in patients with previous (failed) lumbar spinal surgery. Epidural adhesions may compromise nerve root nutrition and contribute to persistent inflammation. Spinal endoscopic adhesiolysis may allow improved nutrition and mobility of lumbar nerves and would allow delivery of therapeutic medications (local anesthetics and steroids) to target nerve roots.

\section{Acknowledgements}

The authors wish to thank Elias Veizi, MD, PhD, research associate, Department of Anesthesiology, University Hospitals Case Medical Center for his advice and assistance in the literature search and manuscript revision; the editorial board of Pain Physician for review and constructive criticism of the manuscript; Sekar Edem and Vidyasagar Pampati, MSc, statistician, for their assistance with the bibliography; and Tonie M. Hatton and Diane E. Neihoff, transcriptionists (Pain Management Center of Paducah), for assistance in the preparation of this manuscript.

\section{References}

1. Boswell MV, Trescot AM, Datta S, Schultz DM, Hansen HC, Abdi S, Sehgal N, Shah RV, Singh V, Benyamin RM, Patel VB, Buenaventura RM, Colson JD, Cordner HJ, Epter RS, Jasper JF, Dunbar EE, Atluri SL, Bowman RC, Deer TR, Swicegood JR, Staats PS, Smith HS, Burton AW, Kloth DS, Giordano J, Manchikanti L. Interventional techniques: Evidencebased practice guidelines in the management of chronic spinal pain. Pain Physician 2007; 10:7-111.
2. Schofferman J, Reynolds J, Herzog R, Covington E, Dreyfuss P, O'Neill C. Failed back surgery: Etiology and diagnostic evaluation. Spine J 2003; 3:400403.

3. Slipman $\mathrm{CW}$, Shin $\mathrm{CH}$, Patel $\mathrm{RK}$, Isaac Z, Huston CW, Lipetz JS, Lenrow DA, Braverman DL, Vresilovic EJ Jr. Etiologies of failed back surgery syndrome. Pain Med 2002; 3:200-214.

4. Waguespack A, Schofferman J, Slosar $\mathrm{P}$, Reynolds J. Etiology of long-term fail- ures of lumbar spine surgery. Pain Med 2002; 3:18-22.

5. Waddell G, Kummel EG, Lotto WN, Graham JD, Hall H, McCulloch JA. Failed lumbar disc surgery and repeat surgery following industrial injury. J Bone Joint Surg Am 1979; 61:201-207.

6. Ross JS, Robertson JT, Frederickson RC, Petrie JL, Obuchowski N, Modic MT, de Tribolet N. Association between peridural scar and recurrent radicular pain after lumbar discectomy: Magnetic reso- 
nance evaluation. Neurosurgery 1996; 38:855-863.

7. Fritsch EW, Heisel J, Rupp S. The failed back surgery syndrome. Reasons, intraoperative findings, and long-term results: A report of 182 operative treatments. Spine 1996; 21:626-633.

8. Osterman H, Sund R, Seitsalo S, Keskimaki I. Risk of multiple reoperations after lumbar discectomy: A populationbased study. Spine 2003; 28:621-627.

9. Bono CM, Lee CK. Critical analysis of trends in fusion for degenerative disc disease over the past 20 years: Influence of technique of fusion rate and clinical outcome. Spine 2004; 29:455463.

10. Law JD, Lehman RAW, Kirsch WM. Reoperation after lumbar intervertebral disc surgery. J Neurosurg 1978; 48:259263.

11. Mirza SK, Deyo RA. Systematic review of randomized trials comparing lumbar fusion surgery to nonoperative care for treatment of chronic back pain. Spine 2007; 32:816-823.

12. Lieberman IH. Disc bulge bubble: Spine economics 101. Spine J 2004; 4:609613.

13. Deyo RA, Nachemson A, Mirza SK. Spinal fusion surgery - The case for restraint. N Engl J Med 2004; 350:722726.

14. Deyo RA, Mirza SK. Trends and variations in the use of spine surgery. Clin Orthop Relat Res 2006; 443:139-146.

15. ECRI Health Technology Assessment Group. Treatment of degenerative lumbar spinal stenosis. Evid Rep Technol Assess 107Summ) 2001; 32:1-5.

16. Weinstein JN, Lurie JD, Olson PR, Bronner KK, Fisher ES. United States' trends and regional variations in lumbar spine surgery: 1992 - 2003. Spine 2006; 31:2707-2714.

17. Brox Jl, Sørensen R, Friis A, Nygaard $\varnothing$, Indahl A, Keller A, Ingebrigtsen T, Eriksen HR, Holm I, Koller AK, Riise R, Reikerås O. Randomized clinical trial of lumbar instrumented fusion and cognitive intervention and exercises in patients with chronic low back pain and disc degeneration. Spine 2003; 28:1913-1921.

18. Katz JN. Lumbar spinal fusion. Surgical rates, costs, and complications. Spine 1995; 20:78S-83S.

19. Cummins J, Lurie JD, Tosteson TD, Hanscom B, Abdu WA, Birkmeyer NJ, Herkowitz $\mathrm{H}$, Weinstein J. Descriptive epidemiology and prior healthcare utilization of patients in the Spine Patient Outcomes Research Trial's (SPORT) three observational cohorts: Disc herniation, spinal stenosis, and degenerative spondylolisthesis. Spine 2006; 31:806814.

20. Weinstein JN, Tosteson TD, Lurie JD, Tosteson AN, Blood E, Hanscom B, Herkowitz $H$, Cammisa $F$, Albert $T$, Boden SD, Hilibrand A, Goldberg H, Berven $\mathrm{S}$, An H; SPORT Investigators. Surgical versus nonsurgical therapy for lumbar spinal stenosis. N Engl J Med 2008; 358:794-810.

21. Deyo RA, Gray DT, Kreuter W, Mirza S, Martin Bl. United States trends in lumbar fusion surgery for degenerative conditions. Spine 2005; 30:1441-1445.

22. Weiner BK, Levi BH. The profit motive and spine surgery. Spine 2004; 29:2588-2591

23. Harkness EF, Macfarlane GJ, Silman AJ, McBeth J. Is musculoskeletal pain more common now than 40 years ago?: Two population-based cross-sectional studies. Rheumatology (Oxford) 2005; 44:890-895.

24. Freburger JK, Holmes GM, Agans RP, Jackman AM, Darter JD, Wallace AS, Castel LD, Kalsbeek WD, Carey TS. The rising prevalence of chronic low back pain. Arch Intern Med 2009; 169:251258

25. Massie JB, Huang B, Malkmus S, Yaksh TL, Kim CW, Garfin SR, Akeson WH. A preclinical post laminectomy rat model mimics the human post laminectomy syndrome. J Neurosci Methods 2004; 137:283-289.

26. Massie JB, Schimizzi AL, Huang B, Kim CW, Garfin SR, Akeson WH. Topical high molecular weight hyaluronan reduces radicular pain post laminectomy in a rat model. Spine J 2005; 5:494-502.

27. Harrington JF, Messier AA, Hoffman L, Yu E, Dykhuizen M, Barker K. Physiological and behavioral evidence for focal nociception induced by epidural glutamate infusion in rats. Spine 2005; 30:606612.

28. Haq I, Cruz-Almeida Y, Siqueira EB, Norenberg $M$, Green BA, Levi AD. Postoperative fibrosis after surgical treatment of the porcine spinal cord: A comparison of dural substitutes. Invited submission from the Joint Section Meeting on Disorders of the Spine and Peripheral Nerves, March 2004. J Neurosurg
Spine 2005; 2:50-54

29. Buvanendran A, Kroin JS, Kerns JM, Nagalla SN, Tuman KJ. Characterization of a new animal model for evaluation of persistent postthoracotomy pain. Anesth Analg 2004; 99:1453-1460.

30. Kim KD, Wang JC, Robertson DP, Brodke DS, BenDebba M, Block KM, diZerega GS. Reduction of leg pain and lower-extremity weakness for 1 year with Oxiplex/SP gel following laminectomy, laminotomy, and discectomy. Neurosurg Focus 2004; 17:ECP1.

31. Manchikanti $L$, Bakhit $C E$, Pampati V. Role of epidurography in caudal neuroplasty. Pain Digest 1998; 8:277-281.

32. Manchikanti L, Manchukonda R, Pampati V, Damron KS, McManus CD. Prevalence of facet joint pain in chronic low back pain in postsurgical patients by controlled comparative local anesthetic blocks. Arch Phys Med Rehabil 2007; 88:449-455.

33. Maliszewski $M$, Tymowski $M$, Lelek $P$, Bierzynska-Macyszyn G, Majchrzak H. An attempt to use Gore-Tex surgical membrane in lumbar disc surgery. $\mathrm{Neu}$ rol Neurochir Pol 2004; 38:271-277.

34. Kayaoglu CR, Calikoglu C, Binler S. Reoperation after lumbar disc surgery: Results in 85 cases. J Int Med Res 2003; 31:318-323.

35. Manchikanti L, Singh V. Epidural lysis of adhesions and myeloscopy. Curr Pain Headache Rep 2002; 6:427-435.

36. Manchikanti L, Saini B, Singh V. Spinal endoscopy and lysis of epidural adhesions in the management of chronic low back pain. Pain Physician 2001; 4:240-265.

37. Manchikanti L, Heavner JE, Boswell MV. Endoscopic lumbar epidural adhesiolysis. In Manchikanti L, Singh V (eds). Interventional Techniques in Chronic Spinal Pain, ASIPP Publishing, Paducah, KY, 2007; pp 507-526.

38. Hoyland JA, Freemont AJ, Jayson M. Intervertebral foramen venous obstruction. A cause of periradicular fibrosis? Spine 1989; 14:558-568.

39. Rydevik BL. The effects of compression on the physiology of nerve roots. J Manipulative Physiol Ther 1992; 15:62-66.

40. Songer M, Ghosh L, Spencer D. Effects of sodium hyaluronate on peridural fibrosis after lumbar laminectomy and discectomy. Spine 1990; 15:550-554.

41. North RB, Campbell JN, James CS, Conover-Walker MK, Wang H, Pianta- 
dosi S, Rybock JD, Long DM. Failed back surgery syndrome: 5-year followup in 102 patients undergoing repeated operation. Neurosurgery 1991; 28:685690.

42. Dullerud R, Graver V, Haakonsen $M$, Haaland AK, Loeb M, Magnaes B. Influence of fibrinolytic factors on scar formation after lumbar discectomy. A magnetic resonance imaging followup study with clinical correlation performed 7 years after surgery. Spine 1998; 23:1464-1469.

43. Pawl RP. Arachnoiditis and epidural fibrosis: The relationship to chronic pain. Curr Rev Pain 1998; 2:93-99.

44. Annertz $M$, Jönsson $B$, Stromquist $B$, Holtas S. No relationship between epidural fibrosis and sciatica in the lumbar post-discectomy syndrome: A study with contrast-enhancement magnetic resonance imagery in symptomatic and asymptomatic patients. Spine 1995; 20:449-453.

45. Larocca $\mathrm{H}$, MacNab I. The laminectomy membrane. J Bone Joint Surg Br 1974; 56B:545-550.

46. McCarron RF, Wimpee MW, Hudkins PG, Laros GS. The inflammatory effects of nucleus pulposus: A possible element in the pathogenesis of low back pain. Spine 1987; 12:760-764.

47. Parke WW, Watanabe R. Adhesions of the ventral lumbar dura. An adjunct source of discogenic pain? Spine 1990; 15:300-303.

48. Manchikanti L. Medicare in interventional pain management: A critical analysis. Pain Physician 2006; 9:171198.

49. Manchikanti L, Giordano J. Physician payment 2008 for interventionalists: Current state of health care policy. Pain Physician 2007; 10:607-626.

50. Manchikanti L. Health care reform in the United States: Radical surgery needed now more than ever. Pain Physician 2008; 11:13-42.

51. Specialty Utilization data files from Centers for Medicare and Medicaid Services. Medicare: www.cms.hhs.gov/

52. Friedly J, Chan L, Deyo R. Increases in lumbosacral injections in the Medicare population: 1994 to 2001. Spine 2007; 32:1754-1760.

53. Friedly J, Chan L, Deyo R. Geographic variation in epidural steroid injection use in Medicare patients. J Bone Joint Surg Am 2008; 90:1730-1737.
54. Manchikanti L, Singh V, Pampati V Smith HS, Hirsch J. Analysis of growth in interventional techniques in managing chronic pain in Medicare population: A 10-year evaluation from 1997 to 2006. Pain Physician 2009; 12:9-34.

55. Manchikanti L, Hirsch JA. Issues in Health Care: Interventional pain management at the crossroads. Health policy update. Pain Physician 2007; 10:261-284.

56. Manchikanti L. The growth of interventional pain management in the new millennium: A critical analysis of utilization in the Medicare population. Pain Physician 2004; 7:465-482.

57. Abdi S, Datta S, Trescot AM, Schultz DM, Adlaka R, Atluri SL, Smith HS, Manchikanti L. Epidural steroids in the management of chronic spinal pain A systematic review. Pain Physician 2007; 10:185-212.

58. Abdi S, Datta S, Lucas LF. Role of epidural steroids in the management of chronic spinal pain: A systematic review of effectiveness and complications. Pain Physician 2005; 8:127-143.

59. Boswell MV, Colson JD, Spillane WF. Therapeutic facet joint interventions in chronic spinal pain: A systematic review of effectiveness and complications. Pain Physician 2005; 8:101-114.

60. Staal JB, de Bie R, de Vet HC, Hildebrandt J, Nelemans $P$. Injection therapy for subacute and chronic low-back pain. Cochrane Database Syst Rev 2008; (3):CD001824.

61. Revel M, Auleley GR, Alaoui S, Nguyen M, Duruoz T, Eck-Michaud S, Roux C, Amor B. Forceful epidural injections for the treatment of lumbosciatic pain with post-operative lumbar spinal fibrosis. Rev Rhum Engl Ed 1996; 63:270-277.

62. Hesla PE, Breivik H. Epidural analgesia and epidural steroid injection for treatment of chronic low back pain and sciatica. Tidsskr Nor Laegeforen 1979; 99:936-939.

63. Manchikanti L, Singh V, Cash KA, Pampati V, Datta S. Preliminary results of randomized, equivalence trial of fluoroscopic caudal epidural injections in managing chronic low back pain: Part 3. Post surgery syndrome. Pain Physician 2008; 11:817-831.

64. Manchikanti L, Rivera JJ, Pampati V, Damron KS, McManus CD, Brandon DE, Wilson SR. One day lumbar epidural adhesiolysis and hypertonic saline neurolysis in treatment of chronic low back pain: A randomized, double-blind trial. Pain Physician 2004; 7:177-186.

65. Heavner JE, Racz GB, Raj P. Percutaneous epidural neuroplasty. Prospective evaluation of $0.9 \% \mathrm{NaCl}$ versus $10 \%$ $\mathrm{NaCl}$ with or without hyaluronidase. Reg Anesth Pain Med 1999; 24:202207.

66. Veihelmann A, Devens $C$, Trouillier $\mathrm{H}$, Birkenmaier C, Gerdesmeyer L, Refior $\mathrm{HJ}$. Epidural neuroplasty versus physiotherapy to relieve pain in patients with sciatica: A prospective randomized blinded clinical trial. J Orthop Science 2006; 11:365-369.

67. Manchikanti L, Boswell MV, Rivera JJ, Pampati V, Damron KS, McManus CD, Brandon DE, Wilson SR. A randomized, controlled trial of spinal endoscopic adhesiolysis in chronic refractory low back and lower extremity pain. $B M C$ Anesthesiol 2005; 5:10.

68. Manchikanti L, Singh V, Derby R, Schultz DM, Benyamin RM, Prager JP, Hirsch JA. Reassessment of evidence synthesis of occupational medicine practice guidelines for interventional pain management. Pain Physician 2008; 11:393482.

69. Chopra P, Smith HS, Deer TR, Bowman $\mathrm{RD}$. Role of adhesiolysis in the management of chronic spinal pain: A systematic review of effectiveness and complications. Pain Physician 2005; 8:87100.

70. Trescot AM, Chopra P, Abdi S, Datta S, Schultz DM. Systematic review of effectiveness and complications of adhesiolysis in the management of chronic spinal pain: An update. Pain Physician 2007; 10:129-146.

71. West S, King V, Carey TS, Lohr KN, McKoy N, Sutton SF, Lux L. Systems to Rate the Strength of Scientific Evidence, Evidence Report, Technology Assessment No. 47. AHRQ Publication No. 02E016. Rockville, MD: Agency for Healthcare Research and Quality, 2002. www. thecre.com/pdf/ahrq-system-strength. pdf

72. Koes BW, Scholten RJ, Mens JM, Bouter LM. Efficacy of epidural steroid injections for low-back pain and sciatica: A systematic review of randomized clinical trials. Pain 1995; 63:279-288.

73. Atluri S, Datta S, Falco FJ, Lee M. Systematic review of diagnostic utility and therapeutic effectiveness of thoracic facet joint interventions. Pain Physician 2008; 11:611-629. 
74. Datta S, Lee M, Falco FJE, Bryce DA, Hayek SM. Systematic assessment of diagnostic accuracy and therapeutic utility of lumbar facet joint interventions. Pain Physician 2009; 12:437460.

75. Falco FJE, Erhart S, Wargo BW, Bryce DA, Atluri S, Datta S, Hayek SM. Systematic review of diagnostic utility and therapeutic effectiveness of cervical facet joint interventions. Pain Physician 2009; 12:323-344.

76. Rupert MP, Lee M, Manchikanti L, Datta S, Cohen SP. Evaluation of sacroiliac joint interventions: A systematic appraisal of the literature. Pain Physician 2009; 12:399-418.

77. Frey ME, Manchikanti L, Benyamin RM, Schultz DM, Smith HS, Cohen SP. Spinal cord stimulation for patients with failed back surgery syndrome: A systematic review. Pain Physician 2009; 12:379-397.

78. Patel VB, Manchikanti L, Singh V, Schultz DM, Hayek SM, Smith HS. Systematic review of intrathecal infusion systems for long-term management of chronic non-cancer pain. Pain Physician 2009; 12:345-360.

79. Conn A, Buenaventura RM, Datta S, Abdi S, Diwan S. Systematic review of caudal epidural injections in the management of chronic low back pain. Pain Physician 2009; 12:109-135.

80. Parr AT, Diwan S, Abdi S. Lumbar interlaminar epidural injections in managing chronic low back and lower extremity pain: A systematic review. Pain Physician 2009; 12:163-188.

81. Benyamin RM, Singh V, Parr AT, Conn A, Diwan S, Abdi S. Systematic review of the effectiveness of cervical epidurals in the management of chronic neck pain. Pain Physician 2009; 12:137-157.

82. Buenaventura RM, Datta $S$, Abdi $S$, Smith HS. Systematic review of therapeutic lumbar transforaminal epidural steroid injections. Pain Physician 2009; 12:233-251.

83. Epter RS, Helm S, Hayek SM, Benyamin RM, Smith HS, Abdi S. Systematic Review of percutaneous adhesiolysis and management of chronic low back pain in post lumbar surgery syndrome. Pain Physician 2009; 12:361-378.

84. van Tulder $M$, Furlan $A$, Bombardier C, Bouter L, Editorial Board of the Cochrane Collaboration Back Review Group. Updated method guidelines for systematic reviews in the Cochrane Col- laboration Back Review Group. Spine 2003; 28:1290-1299.

85. Salaffi $F$, Stancati A, Silvestri CA, Ciapetti A, Grassi W. Minimal clinically important changes in chronic musculoskeletal pain intensity measured on a numerical rating scale. Eur J Pain 2004; 8:283-291.

86. Bombardier C. Outcome assessments in the evaluation of treatment of spinal disorders: Summary and general recommendations. Spine 2000; 25:31003103.

87. Manchikanti L, Boswell MV, Giordano J. Evidence-based interventional pain management: Principles, problems, potential, and applications. Pain Physician 2007; 10:329-356.

88. Manchikanti L. Evidence-based medicine, systematic reviews, and guidelines in interventional pain management: Part 1: Introduction and general considerations. Pain Physician 2008, 11:161-186.

89. Manchikanti L, Hirsch JA, Smith HS. Evidence-based medicine, systematic reviews, and guidelines in interventional pain management: Part 2: Randomized controlled trials. Pain Physician 2008; 11:717-773

90. Manchikanti L, Benyamin RM, Helm S, Hirsch JA. Evidence-based medicine, systematic reviews, and guidelines in interventional pain management: Part 3: Systematic reviews and meta-analysis of randomized trials. Pain Physician 2009; 12:35-72.

91. Manchikanti L, Singh V, Smith HS, Hirsch JA. Evidence-based medicine, systematic reviews, and guidelines in interventional pain management: Part 4: Observational studies. Pain Physician 2009; 12:73-108.

92. Berg AO, Allan JD. Introducing the third U.S. Preventive Services Task Force. Am J Prev Med 2001; 20:S3-S4.

93. Guyatt $\mathrm{G}$, Gutterman D, Baumann $\mathrm{MH}$ Addrizzo-Harris D, Hylek EM, Phillips B, Raskob G, Lewis SZ, Schünemann $\mathrm{H}$. Grading strength of recommendations and quality of evidence in clinical guidelines. Report from an American College of Chest Physicians Task Force. Chest 2006; 129:174-181.

94. Warnke JP, Mourgela S. Endoscopic treatment of lumbar arachnoiditis. Minim Invasive Neurosurg 2007; 50:16.

95. Saberski LR. A retrospective analysis of spinal canal endoscopy and laminec- tomy outcomes data. Pain Physician 2000; 3:193-196.

96. Manchikanti L, Rivera JJ, Pampati V, Damron KS, Beyer CD, Brandon DE, Wilson SR. Spinal endoscopic adhesiolysis in the management of chronic low back pain: A preliminary report of a randomized, double-blind trial. Pain Physician 2003; 6:259-267.

97. Avellanal M, Diaz-Reganon G. Interlaminar approach for epiduroscopy in patients with failed back surgery syndrome. Br J Anaesth 2008; 101:244249.

98. Dashfield AK, Taylor MB, Cleaver JS, Farrow D. Comparison of caudal steroid epidural with targeted steroid placement during spinal endoscopy for chronic sciatica: A prospective, randomized, double-blind trial. $\mathrm{Br} / \mathrm{An}$ aesth 2005; 94:514-519.

99. Geurts JW, Kallewaard JW, Richardson J, Groen GJ. Targeted methylprednisolone acetate/hyaluronidase/clonidine injection after diagnostic epiduroscopy for chronic sciatica: A prospective, 1year follow-up study. Reg Anesth Pain Med 2002; 27:343-352.

100. Igarashi T, Hirabayashi Y, Seo N, Saitoh K, Fukuda H, Suzuki H. Lysis of adhesions and epidural injection of steroid/ local anaesthetic during epiduroscopy potentially alleviate low back and leg pain in elderly patients with lumbar spinal stenosis. Br J Anaesth 2004; 93:181-187.

101. Richardson J, McGurgan P, Cheema S, Prasad R, Gupta S. Spinal endoscopy in chronic low back pain with radiculopathy. A prospective case series. Anaesthesia 2001; 56:454-460.

102. Sakai T, Aoki H, Hojo M, Takada M, Murata $\mathrm{H}$, Sumikawa K. Adhesiolysis and targeted steroid/local anesthetic injection during epiduroscopy alleviates pain and reduces sensory nerve dysfunction in patients with chronic sciatica. J Anesth 2008; 22:242-247.

103. Manchikanti L, Pampati V, Bakhit CE, Pakanati RR. Non-endoscopic and endoscopic adhesiolysis in post-lumbar laminectomy syndrome: A one-year outcome study and cost effectiveness analysis. Pain Physician 1999; 2:5258.

104. Manchikanti L, Pakanati, RR, Pampati $V$, Fellows $B$. The value and safety of epidural endoscopic adhesiolysis. Am J Anesthesiol 2000; 27:275-279.

105. Helm S, Gross JD, Varley KG. Mini-sur- 
gical approach for spinal endoscopy in the presence of stenosis of the sacral hiatus. Pain Physician 2004; 7:323325.

106. Takeshima N, Miyakawa H, Okuda K, Hattori S, Hagiwara S, Takatani J, Noguchi T. Evaluation of the therapeutic results of epiduroscopic adhesiolysis for failed back surgery syndrome. $\mathrm{Br} / \mathrm{An}$ aesth 2009; 102:400-407.

107. Altman DG, Schulz KF, Moher D, Egger M, Davidoff F, Elbourne D, Gøtzsche PC, Lang T; CONSORT GROUP (Consolidated Standards of Reporting Trials). The revised CONSORT statement for reporting randomized trials: Explanation and elaboration. Ann Intern Med 2001; 134:663-694.

108. Piaggio G, Elbourne DR, Altman DG, Pocock SJ, Evans SJ; CONSORT Group. Reporting of noninferiority and equivalence randomized trials: An extension of the CONSORT statement. JAMA 2006; 295:1152-1160.

109. Moher $D$, Schulz KF, Altman D, for the CONSORT Group. The CONSORT statement: Revised recommendations for improving the quality of reports of parallel-group randomized trials. JAMA 2001; 285:1987-1991.

110. Manchikanti L, Cash KA, McManus CD, Pampati V, Smith HS. Preliminary results of randomized, equivalence trial of fluoroscopic caudal epidural injections in managing chronic low back pain: Part 1. Discogenic pain without disc herniation or radiculitis. Pain Physician 2008; 11:785-800.

111. Manchikanti L, Singh V, Cash KA, Pam- pati V, Damron KS, Boswell MV. Preliminary results of randomized, equivalence trial of fluoroscopic caudal epidural injections in managing chronic low back pain: Part 2. Disc herniation and radiculitis. Pain Physician 2008, 11:801-815

112. Manchikanti L, Singh V, Falco FJE, Cash $K A$, Pampati V. Effectiveness of thoracic medial branch blocks in managing chronic pain: A preliminary report of a randomized, double-blind controlled trial; Clinical trial NCT00355706. Pain Physician 2008; 11:491-504.

113. Manchikanti L, Singh V, Falco FJ, Cash KA, Fellows B. Cervical medial branch blocks for chronic cervical facet joint pain: A randomized double-blind, controlled trial with one-year follow-up. Spine 2008; 33:1813-1820.

114. Manchikanti L, Singh V, Falco FJ, Cash KA, Pampati V. Lumbar facet joint nerve blocks in managing chronic facet joint pain: One-year follow-up of a randomized, double-blind controlled trial: Clinical Trial NCT00355914. Pain Physician 2008; 11:121-132.

115. Schulze $C$, Bittorf $T$, Walzel $H$, Kundt $\mathrm{G}$, Bader R, Mittelmeier W. Experimental evaluation of hyaluronidase activity in combination with specific drugs applied in clinical techniques of interventional pain management and local anaesthesia. Pain Physician 2008; 11:877-883.

116. Gill JB, Heavner JE. Visual impairment following epidural fluid injections and epiduroscopy: A review. Pain Med $2005 ; 6: 367-374$.
117. Heavner JE, Wyatt DE, Bosscher HA. Lumbosacral epiduroscopy complicated by intravascular injection. Anesthesiology 2007; 107:347-350.

118. Manchikanti L. Role of neuraxial steroids in interventional pain management. Pain Physician 2002; 5:182-199.

119. Benyamin RM, Vallejo R, Kramer J, Rafeyan R. Corticosteroid induced psychosis in the pain management setting. Pain Physician 2008; 11:917-920.

120. Simopoulos TT, Kraemer JJ, Glazer P, Bajwa ZH. Vertebral osteomyelitis: A potentially catastrophic outcome after lumbar epidural steroid injection. Pain Physician 2008; 11:693-697.

121. Manchikanti L, Pampati VS, Beyer CD, Damron KS, Cash KA, Moss TL. The effect of neuraxial steroids on weight and bone mass density: A prospective evaluation. Pain Physician 2000; 3:357366.

122. Manchikanti L, Singh V, Helm S, Trescot AM, Hirsch JA. A critical appraisal of 2007 American College of Occupational and Environmental Medicine (ACOEM) practice guidelines for interventional pain management: An independent review utilizing AGREE, AMA, IOM, and other criteria. Pain Physician 2008; 11:291-310.

123. Manchikanti L, Singh V, Derby $R$, Helm S, Trescot AM, Staats PS, Prager JP, Hirsch JA. Review of occupational medicine practice guidelines for interventional pain management and potential implications. Pain Physician 2008; 11:271-289. 
